\title{
Optimalisasi Daya Mesin Diesel Common Rail
}

\author{
Ridwan \\ Unit Pelaksana Pendidikan dan pelatihan Bogor, Indonesia \\ ridwan6487005d@gmail.com
}

\begin{abstract}
This research aims is to increase engine power by raising the air temperature and fuel temperature into the engine and its effect on the resulting of SFC. Diesel engines that are use turbocharger, the air temperatures have increased but the fuel temperature is still fixed. The problem is how if the air temperature and fuel temperature are raised whether the engine power will increase and the SFC will change. This study was conducted with experiments using a car that the air temperature is adjusted up to $100^{\circ} \mathrm{C}$ and the fuel temperature that goes into the engine is made a maximum of $70^{\circ} \mathrm{C}$. The test results show that with rising air temperatures and fuel temperatures going into the average power engine will raise and save fuel, power and saving $S F C$ occurs at $90^{\circ} \mathrm{C}$ and $70^{\circ} \mathrm{C}$ fuel. Rotation of engine that can produce power and fuel-efficient is at around $2000 \mathrm{rpm}$.
\end{abstract}

Keywords: influence of temperature, air, fuel, SFC, power, diesel

\begin{abstract}
ABSTRAK
Penelitian ini bertujuan untuk meningkatkan tenaga mesin dengan menaikkan suhu udara dan suhu bahan bakar ke dalam mesin dan pengaruhnya terhadap hasil SFC. Mesin diesel yang menggunakan turbocharger, suhu udara sudah meningkat tetapi suhu bahan bakarnya tetap. Masalahnya adalah bagaimana jika suhu udara dan suhu bahan bakar dinaikkan apakah tenaga mesin akan meningkat dan SFC akan berubah. Penelitian ini dilakukan dengan eksperimen menggunakan mobil yang suhunya diatur hingga $100 o C$ dan suhu bahan bakar yang masuk ke mesin dibuat maksimal $70 o C$. Hasil pengujian menunjukkan bahwa dengan meningkatnya suhu udara dan suhu bahan bakar yang masuk ke mesin daya rata-rata akan menaikkan dan menghemat bahan bakar, daya dan penghematan SFC terjadi pada $90{ }^{\circ} \mathrm{C}$ dan 70 oC bahan bakar. Rotasi mesin yang dapat menghasilkan tenaga dan hemat bahan bakar adalah sekitar $2000 \mathrm{rpm}$.
\end{abstract}

Kata kunci: pengaruh suhu, udara, bahan bakar, SFC, daya, diesel 


\section{KILAT}

Vol. 9, No. 1, April 2020, P-ISSN 2089-1245, E-ISSN 2655-4925

DOI: https://doi.org/10.33322/kilat.v9i1.749

\section{PENDAHULUAN}

Reaksi kimia suatu material dipengaruhi oleh suhu, tekanan, luas bidang kontak dan katalis. Dengan dasar ini diambil salah satu dari pernyataan tersebut, yaitu merubah suhu bahan bakar dan suhu udara yang masuk ke mesin yang akan direaksikan di dalam silinder mesin. Peningkatan suhu bahan bakar dan suhu udara diharapkan bisa meningkatkan daya mesin dan menghemat bahan bakar.

Penelitian eksperimen ini memakai mesin diesel yang sudah commonrail dan telah dilengkapi dengan turbocharger, pada umumnya mesin yang telah dilengkapi ini efisiensinya sudah cukup tinggi tapi perlu juga dicari celah-celah yang kemungkinan dapat menaikkan efisiensinya mesin. Penelitian ini suhu udara akan dinaikkan sampai $100^{\circ} \mathrm{C}$ dan suhu bahan bakar dinaikkan $70^{\circ} \mathrm{C}$, memakai batasan ini karena dalam studi awal suhu-suhu tersebut yang paling efektif dan mudah dilakukan.

Perlu diketahui bahwa turbocharger digunakan untuk mendorong udara dari luar masuk ke dalam silinder dengan tekanan yang lebih tinggi dari udara luar, dengan tekanan yang yang lebih tinggi ini akan menyebabkan suhu meningkat dan dalam penelitian ini telah diketahui bahwa suhu bisa meningkat sampai maksimum $80^{\circ} \mathrm{C}$. Kerja turbocharger untuk mesin diesel di kendaraan ringan ini biasanya bekerja maksimal setelah putaran mesin sekitar $2000 \mathrm{rpm}$. Hasil pengukuran suhu di dalam saluran masuk yang dilakukan oleh Yuniar (2017), kenaikan suhu udara tergantung dari putaran mesin semakin tinggi putarannya akan semakin tinggi suhu udara yang masuk ke dalam silinder. Pada umumnya setelah turbocharger dipasang intercooler yang bertujuan untuk menurunkan suhu udara yang akan masuk ke dalam mesin, tetapi peneliti berpendapat lain dengan yang umum tersebut.

Mempertimbangkan bahwa tekanan udara di intake manifold naik, maka jumlah udara yang masuk ke mesin akan naik, dengan demikian menunjukkan bahwa jumlah udara akan berlebihan, sehingga bila jumlah udara dikurangi sedikit maka tidak akan berpengaruh terhadap pembakaran bahan bakar, berkurangnya udara karena disebabkan dari suhu udara dinaikkan.

Bahan bakar dipompa dari tangki ke pompa tekanan tinggi tidak mengalami kenaikan suhu tapi setelah ditekan oleh tekanan tinggi suhu akan naik sampai mencapai sekitar $45^{\circ} \mathrm{C}$, dengan bertambahnya waktu suhu bahan bakar akan turun lagi sampai stabil sekitar $40^{\circ} \mathrm{C}$.

Penelitian yang telah dilakukan oleh beberapa peneliti, seperti penelitian yang dilakukan oleh Rafidah (2012) menyetakan bahwa "Pengaruh suhu bahan bakar pada kinerja mesin diesel menggunakan campuran bio diesel, simulasi dilakukan pada kondisi beban penuh di mana suhu bervariasi dari 300 hingga $500 \mathrm{~K}$ yang menghasilkan adanya peningkatan daya mesin".

Gowthaman (2016) menyatakan bahwa "Brake thermal efficiency meningkat dengan meningkatnya suhu udara masuk dan tekanan injeksi bahan bakar dalam batas tertentu". Sodré, (2003) menyatakan bahwa "Tekanan atmosfer lebih berpengaruh dari pada suhu udara atmosfir yang masuk ke mesin terhadap kinerja mesin". Nematullah (2013) menyatakan bahwa "Penelitian dengan bahan bakar minyak jarak pemanasan awal dibuat suhu bahan bakar $30^{\circ} \mathrm{C}, 50^{\circ} \mathrm{C}, 70^{\circ} \mathrm{C}, 90^{\circ} \mathrm{C}$, dan $110^{\circ} \mathrm{C}$, menghasilkan bahwa suhu $90^{\circ} \mathrm{C}$ adalah suhu yang paling baik dan bila suhunya dinaikkan hasil daya mesin akan turun". Kanna, (2014), menyatakan bahwa "Pengujian dilakukan untuk mengetahui pengaruh pemanasan bahan bakar awal dan hasilnya menunjukkan peningkatan yang signifikan dalam kinerja mesin dan pengurangan tingkat emisi, performa yang lebih baik dan tingkat emisi diamati saat mesin bekerja pada suhu bahan bakar $60^{\circ} \mathrm{C}$ suhu yang baik". Rizalman (2010) menyimpulkan "Bahwa peningkatan suhu masuk menyebabkan pengurangan massa udara ke silinder dan karena itu mengurangi kapasitas oksigen, ini juga akan menghasilkan meningkatnya brake specific fuel consumption (BSFC) pada level rendah tetapi sedikit bisa menurunkan BSFC ketika suhu udara meningkat lagi. Birtok (2017), menyatakan bahwa "Membuat aliran udara masuk 
ke dalam silinder bertekanan lebih tinggi dan mempertahankan suhu udara rendah di sepanjang sistem masukan, berkontribusi bisa meningkatkan efisiensi pengisian silinder mesin dan meningkatkan efisiensi konsumsi bahan bakar dengan BSFC yang lebih rendah dan polutan pembuangan yang lebih rendah". Cinar (2015) menyatakan bahwa "Dalam percobaan menunjukkan bahwa suhu udara masuk yang tinggi meningkatkan suhu gas dalam silinder pada akhir kompresi dan mempercepat reaksi kimia, waktu pengapian dan pembakaran didominasi oleh gas dalam silinder suhu, tekanan, dan komposisi campuran dan waktu pengapian juga sangat dipengaruhi oleh suhu udara masuk dalam pembakaran". Hindren (2013), menyatakan bahwa "Dengan meningkatnya suhu udara masuk ke silinder akan menyebabkan naiknya BSFC pada putaran diatas $2500 \mathrm{rpm}$ dan dibawah putaran tersebut BSFC akan turun". Travis (2013), menyatakan bahwa "efek ketinggian mesin dari kondisi atmosfer yang merupakan gabungan suhu dan tekanan akan menurunkan daya dan meningkatkan komsumsi bahan bakar, setiap kenaikan elevasi $300 \mathrm{~m}$ akan menyebabkan penurunan efisiensi $0.4 \%$ dan peningkatan konsumsi bahan bakar $3 \%$.

\section{FORMULASI PENELITIAN}

Berdasarkan dari buku termodinamika oleh Rajput R.K. (2007) Perhitungan suhu akhir kompresi adalah

$$
\begin{aligned}
& \mathrm{pi}=\text { tekanan awal kompresi } \\
& \mathrm{pc}=\text { tekanan akhir kompresi } \\
& \gamma=\text { perbandingan } \mathrm{cp} / \mathrm{cv}
\end{aligned}
$$

Dari persamaan (1) dan (2) tersebut menunjukkan bahwa semakin tinggi suhu yang masuk akan semakin tinggi suhu hasil kompresinya Reaksi kimia bahan bakar solar di dalam silinder secara teoritis dan sederhana tanpa ada emisi gas tapi ada kelebihan udara,

$\mathrm{C} 16 \mathrm{H} 34+24.5 \lambda(\mathrm{O} 2+3.76 \mathrm{~N} 2) \rightarrow 16 \mathrm{CO} 2+17 \mathrm{H} 2 \mathrm{O}+24.5(\lambda-1) \mathrm{O} 2+92.12 \mathrm{~N} 2$

Perhitungan energi di dalam mesin sekali pembakaran:

$$
\mathrm{Q}=(\mathrm{mf}+\mathrm{ma}) \cdot \mathrm{Cp} \cdot \mathrm{dT}
$$

Dimana $\mathrm{mf}=$ massa bahan bakar

$\mathrm{ma}=$ massa udara

$\mathrm{Cp}=$ panas jenis

$\mathrm{dT}=$ beda suhu

Perhitungan daya pada mesin Diesel 4 tak:

$$
\begin{array}{ll} 
& \mathrm{P}=\mathrm{Q} \cdot \mathrm{n} / 2 \\
\text { Atau } & \mathrm{P}=\text { Tr. } \omega \\
\text { dimana } & \varpi=2 \pi \mathrm{n} / 60 \\
& \mathrm{n}=\text { putaran mesin } \\
& \mathrm{Tr}=\text { torsi } \\
& \omega=\text { kecepatan sudut }
\end{array}
$$

Peningkatan daya adalah selisih antara daya yang dihasilkan karena adanya perubahan suhu dikurangi daya standar pada putaran yang sama, rumusnya:

$$
\mathrm{dP}=\mathrm{P}-\mathrm{Pstd}
$$

$$
\text { dalam satuan }(\%)
$$

$$
\mathrm{dP}=(\mathrm{P}-\mathrm{Pstd}) / \mathrm{Pstd} \times 100 \%
$$

dimana: $\mathrm{dP}=$ peningkatan/penurunan daya

$\mathrm{P}=$ daya mesin

Pstd $=$ daya standar 


\section{KILAT}

Pengaruh turbocharger akan meningkatkan tekanan dan mengakibatkan jumlah massa udara yang masuk ke dalam silinder meningkat. Irawan, (2017) menyatakan dengan meningkatnya massa udara akan menyebabkan pembakaran lebih sempurna.

Sebaliknya dengan bertambahnya suhu udara maka jumlah massa udara yang masuk berkurang, dengan persamaan sederhana untuk gas ideal adalah:

$$
\begin{aligned}
& T_{i}=\left({ }^{V_{i}}\right)(\square\|\| 1) \\
& T_{C} \quad V_{C} \\
& T_{i}=\left(p_{i}\right)(\square\|\| 1) / \\
& T_{c} \quad p_{c}
\end{aligned}
$$

Dimana $\mathrm{Ti}=$ suhu awal masuk ke mesin

$$
\begin{aligned}
& \mathrm{T}_{\mathrm{c}}=\text { suhu akhir kompresi } \\
& \mathrm{Vi}=\text { volume awal kompresi } \\
& \mathrm{V}_{\mathrm{c}}=\text { volume akhir kompresi } \\
& \text { p.v } / \mathrm{T}=\mathrm{c}
\end{aligned}
$$

Dimana $\quad p=$ tekanan gas

$\mathrm{v}=$ volume spesifik

$\mathrm{T}=$ suhu gas atau $\mathbf{c}=$ konstanta

Karakteristik mesin salah satunya adalah jumlah bahan bakar yang dikonsumsi yang biasa disebut the Specific Fuel Consumption (SFC) dalam satuan kilogram per jam bahan bakar dan per HP. Pengambilan data pada penelitian, konsumsi bahan bakar diukur debitnya atau volume bahan bakar per satuan waktu kemudian dikalikan dengan massa jenis bahan bakar dan dibagi dengan daya yang dihasilkan.

$$
\mathrm{SFC}=V_{f} \cdot \square f t f \cdot P
$$

Tahap ke tiga menggabungkan suhu bahan bakar dan udara dipanaskan bersamaan. Suhu udara/bahan bakar dibuat bervariasi $70^{\circ} / 40^{\circ} \mathrm{C}$ (standar), $80^{\circ} / 50^{\circ} \mathrm{C}$,

Perubahan suhu bahan bakar dan udara akan terjadi perubahan SFC, perubahan ini dapat dihitung dengan persamaan:

SFC $\square$ USFCstd $85^{\circ} / 60^{\circ} \mathrm{C}, 90^{\circ} / 70^{\circ} \mathrm{C}, 95^{\circ} / 70^{\circ} \mathrm{C}$ dan $100^{\circ} / 70^{\circ} \mathrm{C}$.

Selama percobaan dilakukan pengukuran pada daya dan jumlah bahan bakar yang dipakai.

$\mathrm{SFC}=$ SFCstd $(12)$

\section{HASIL DAN PEMBAHASAN}

Hasil uji ekperimen seperti pada Gambar 1 sd 6, Gambar ini dibagi menjadi dua bagian, yaitu: Gambar 1 sd 3 adalah

Dimana Vf = volume bahan bakar

tf = waktu pemakaian bahan bakar

$\mathrm{P}=$ daya mesin

$\rho f=$ massa jenis bahan bakar SFCstd $=$ SFC standar 
Dengan adanya kenaikan suhu maka volume bahan bakar maupun udara akan membesar, sesuai dengan persamaan dasar: hasil uji daya dan Gambar 4 sd 6 adalah hasil pemakaian bahan bakar. Data pada keadaan mesin standar yaitu pada suhu udara $70{ }^{\circ} \mathrm{C}$ dan bahan bakar $40^{\circ} \mathrm{C}$ tidak ada (perlakuan apapun). Grafik hasil percobaan seperti garis 80/50 adalah menunjukkan suhu udara 80 ${ }^{\circ} \mathrm{C}$ dan suhu bahan bakar $40{ }^{\circ} \mathrm{C}$, begitu untuk yang lainnya.

$$
\mathrm{Vt}=\mathrm{Vo} \beta .(\mathrm{Tt}-\mathrm{To})
$$

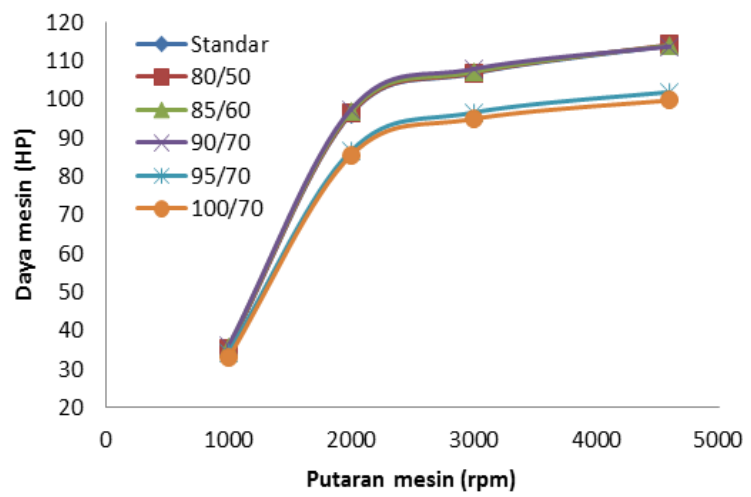

Gambar 1. Grafik pengaruh putaran mesin terhadap daya dengan berdasarkan suhu udara dan suhu bahan bakar.

Dimana $\mathrm{Vt}=$ volume pada suhu $\mathrm{t}$

Dengan adanya perubahan volume massa jenisnya akan berubah sesuai dengan persamaan dibawah ini.

$\mathrm{m} \rho \mathrm{t}=\mathrm{Vt}(\mathrm{t} 4$ dimana $\rho \mathrm{t}=$ massa jenis saat $\mathrm{t} \mathrm{m}=$ massa $\mathrm{Vt}=$ volume saat $\mathrm{t}$

\section{METODE PENELITIAN}

Simulasi dilakukan experiment dengan memakai mesin Diesel Catterfilar dengan spesifikasi sebagai berikut:

Isi silinder $3400 \mathrm{cc}$, putaran mesin maksimum $1500 \mathrm{rpm}$, perbandingan kompresi 20, turbocharger dan intercooler 1 unit, daya maksimum 320 KVA dan bahan bakar minyak solar.

Alat uji yang dipakai adalah pengukur daya dan torsi serta pengukur konsumsi bahan bakar dengan spesifikasi seperti berikut: Single-dynamometers, static power of $260 \mathrm{~kW}$ up to $2 \times 460 \mathrm{~kW}$, dynamic power of $400 \mathrm{~kW}$ up to $2 \times 600 \mathrm{~kW}$, Max. test speed $260 \mathrm{~km} / \mathrm{h}$, Max. brakeable wheel power $\mathrm{kW} / \mathrm{km} / \mathrm{h} 260 / 260$ Max. power in program P-max $\mathrm{kW} / \mathrm{km} / \mathrm{h} 400 / 260$ Preset constant velocity $\mathrm{km} / \mathrm{h}$ 0-260 Power supply V 3/N/PE $400 \mathrm{~V}$ AC Frequency Hz 50 Slow-blow fuses A 25 Compressedair supply bar 7 Length $x$ width $x$ max. height mm 3270x1050x654 Roller diameter mm 320 Roller distance mm 490 Usable roller width min. - max. mm 800-2200 Vertical lift mm 70 Rated capacity of lift t 2 Max. axle load t 3.5.

Pemanas bahan bakar diletakkan setelah pompa dan pemanas udara diletakkan di dalam intake manifold Percobaan dilakukan seperti berikut: 


\section{KILAT}

Vol. 9, No. 1, April 2020, P-ISSN 2089-1245, E-ISSN 2655-4925

DOI: https://doi.org/10.33322/kilat.v9i1.749

1. Tahap pertama meneliti pada keadaan normal standar tanpa perlakuan.

2. Tahap kedua dilanjutkan dengan menaikkan suhu bahan bakar dari normal $40^{\circ} \mathrm{C}$ menjadi $50^{\circ} \mathrm{C}, 60^{\circ} \mathrm{C}$ dan $70^{\circ} \mathrm{C}$.

Gambar 1 menunjukkan hasil percobaan pengaruh putaran mesin terhadap daya yang dihasilkan pada keadaan setiap perubahan suhu udara dan suhu bahan bakar. Dari grafik menunjukkan bahwa semakin tinggi putaran mesin akan semakin tinggi daya yang dihasilkan dan ini berlaku untuk semua perlakuan suhu udara dan suhu bahan bakar. Hubungan tersebut tidak linier dan terjadi pembelokan grafik pada putaran 2000 rpm daya tetap naik tapi landau.

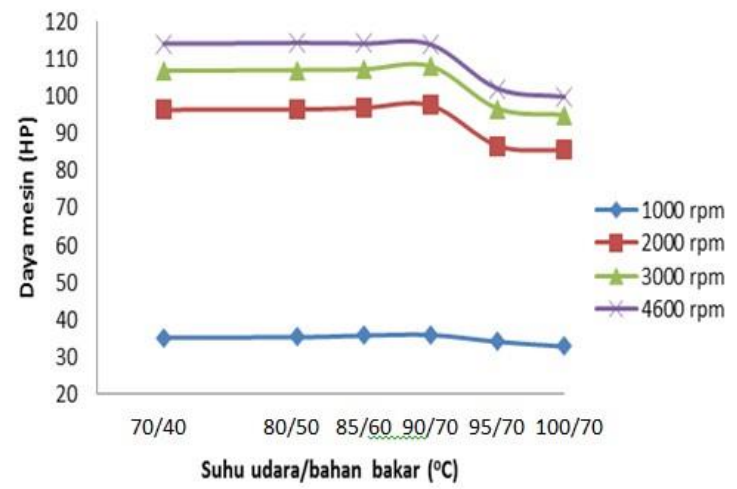

Gambar 2. Grafik pengaruh suhu udara dan suhu bahan bakar terhadap daya dengan berdasarkan putaran mesin

Gambar 2 menunjukkan pengaruh dari suhu udara dan suhu bahan bakar terhadap daya yang dihasilkan pada putaran mesin yang berbeda. Dari grafik menunjukkan bahwa semakin tinggi perpaduan antara suhu udara dan suhu bahan bakar dayanya relative tetap dan pada suhu udara dan bahan bakar 90/70 menunjukkan adanya peningkatan daya yang dihasilkan. Suhu udara/bahan bakar setelah 90/70 daya yang dihasilkan akan turun drastis dan bahkan akan lebih rendah dari yang standar.

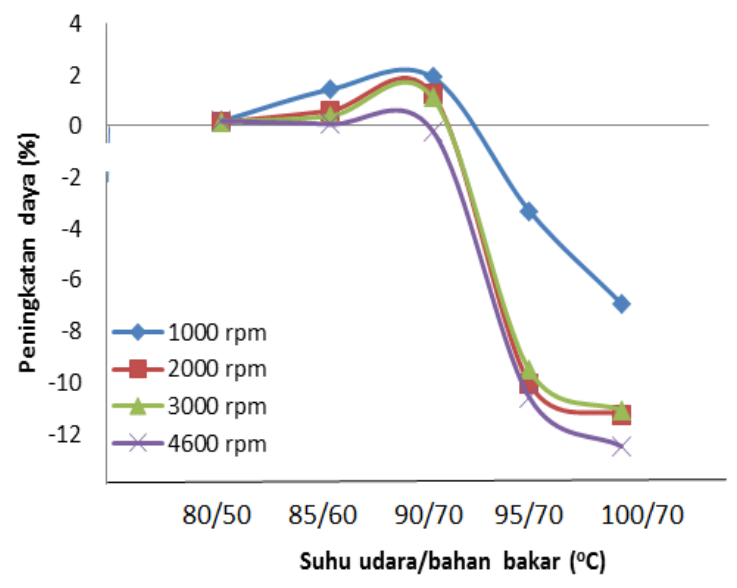

Gambar 3. Grafik peningkatan daya akibat dari pengaruh perubahan suhu udara dan suhu bahan bakar 
Grafik gambar 3 menunjukkan pengaruh suhu udara/suhu bahan bakar terhadap peningkatan daya pada putaran yang berbeda. Pada gambar menunjukkan bahwa suhu semakin naik peningkatannya semakin naik, dan terjadi kenaikkan daya maksimum sampai sekitar 2,5\% pada suhu $90 / 70^{\circ} \mathrm{C}$ setelah itu akan turun drastis sampai minus karena lebih rendah dari standar.

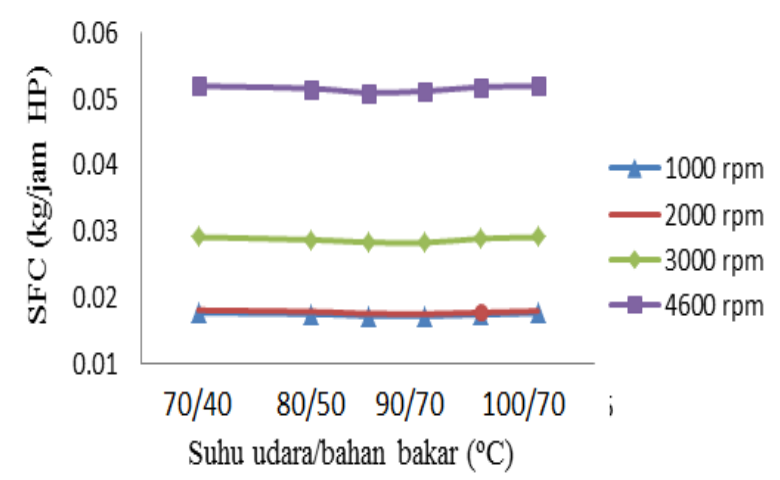

Gambar 4. Pengaruh suhu udara. bahan bakar dan putaran mesin terhadap SFC

Gambar 4 menunjukkan pengaruh suhu udara/suhu bahan bakar terhadap pemakaian bahan bakar (SFC) pada putaran mesin yang berbeda, grafiknya hampir lurus datar dan kelihatan pada putaran tertentu terjadi penurunan pada suhu $85 / 60^{\circ} \mathrm{C}$. Putaran mesin berpengaruh terhadap SFC dan ada yang hamper sama pada putaran $1000 \mathrm{rpm}$ dengan $2000 \mathrm{rpm}$.

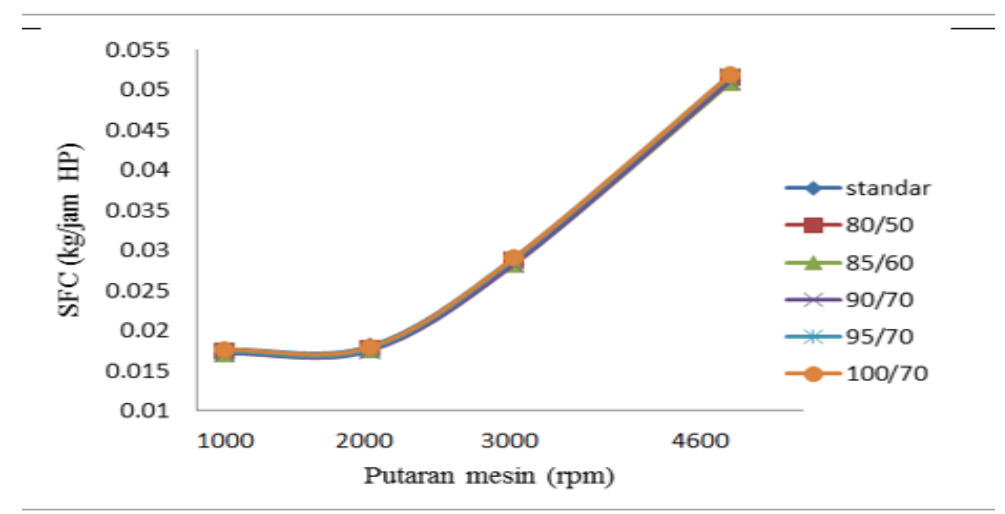

Gambar 5. Pengaruh putaran mesin dan suhu udara/bahan bakar terhadap SFC

Grafik pada Gambar 5 menunjukkan pengaruh putaran mesin terhadap SFC pada suhu udara/bahan bakar yang berbeda. Grafik menunjukkan garisnya hamper linier setelah putaran mesin $2000 \mathrm{rpm}$, nilai SFC pada putaran $1000 \mathrm{rpm}$ hamper sama dengan putaran $2000 \mathrm{rpm}$. Satuan massa pada SFC adalah kg sehingga perbedaan antara setiap beda suhu tidak begitu kelihatan maka garisnya terlihat berimpit. 


\section{KILAT}

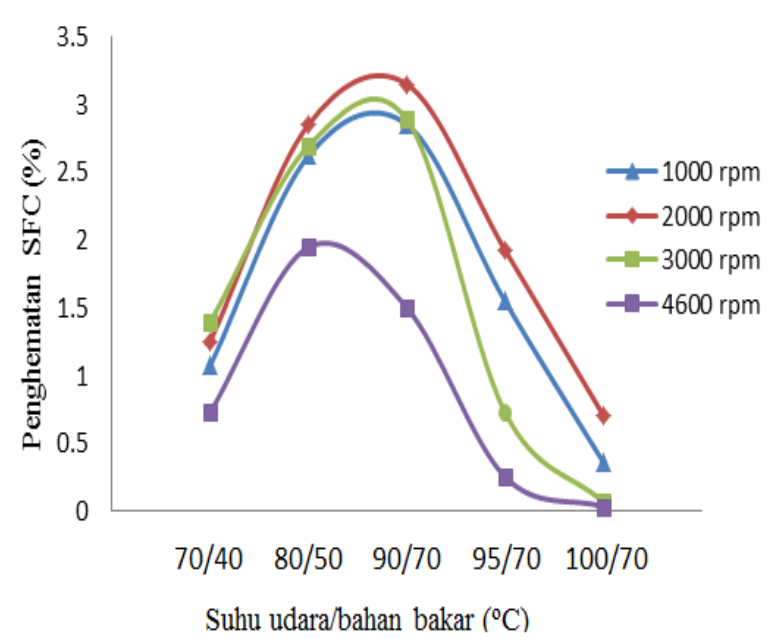

Gambar 6. Pengaruh suhu udara, bahan bakar dan putaran mesin terhadap penghematan SFC.

Grafik pada Gambar 6 adalah pengaruh suhu udara/bahan bakar terhadap SFC pada putaran mesin yang berbeda menunjukkan bahwa terjadi penghematan maksimal sekitar pada suhu udara $90^{\circ} \mathrm{C}$ dan suhu bahan bakar $70^{\circ} \mathrm{C}$. Pada putaran mesin yang berbeda terjadi penghematan yang berbeda pula.

Hasil penelitian eksperimen menunjukkan bahwa semua variable yang diteliti seperti putaran mesin, suhu udara dan suhu bahan bakar sangat berpengaruh terhadap daya mesin dan SFC, sehingga perlu dibahas penyebabnya terjadi seperti itu.

Berdasarkan hasil penelitian yang telah di buat grafik seperti pada Gambar 1, menunjukkan bahwa semakin tinggi putaran mesin akan semakin tinggi daya yang dihasilkan hal ini benar karena disebabkan bahwa daya berbanding lurus dengan putaran mesin sesuai dengan persamaan no (5) dan (6). Jika persamaan tersebut berlaku secara umum maka grafiknya akan lurus tapi pada gambar terlihat terjadi pembelokan pada putaran 2000 rpm dayanya naik tapi landai, hal ini bisa disebabkan dari beberapa hal seperti:

1) Gesekan mekanik yang terjadi setelah putaran $2000 \mathrm{rpm}$ tinggi, sehingga daya yang dihasilkan akan diserap oleh daya gesek mekanik.

2) Semakin cepat putaran mesin akan semakin cepat gerakan piston akibatnya pemasukan udara ke dalam silinder kurang maksimal akibatnya oksigen kurang dan pembakaran sesuai persamaan (3) kurang terpenuhi.

Dari Gambar 1 menunjukkan bahwa suhu udara dan bahan bakar berpengaruh terhadap daya yang dihasilkan hal ini terlihat bahwa suhu udara dan suhu bahan bakar $90 / 70^{\circ} \mathrm{C}$ yang menghasilkan daya yang lebih besar dari yang lainnya.

Berdasarkan hasil penelitian yang telah dibuat grafik seperti pada Gambar 2, menunjukkan bahwa semakin tinggi suhu udara dan suhu bahan bakar akan semakin tinggi daya yang dihasilkan biarpun kenaikannya hanya sedikit hal ini benar karena disebabkan bahwa daya dipengaruhi oleh suhu, semakin tinggi suhu udara akan semakin tinggi suhu kompresinya sesuai dengan persamaan (1) dan (2). Suhu bahan bakar semakin tinggi akan menyebabkan bahan bakar mudah mengabut sehingga bidang kontak antara bahan bakar dengan oksigen akan lebih luas akibatnya pembakaran bisa lebih mudah terbakar dan sempurna.

Gambar 2 menunjukkan bahwa kenaikan daya tidak bisa terjadi linier karena pada suhu udara dan bahan bakar $90 / 70^{\circ} \mathrm{C}$ terjadi kenaikan yang lebih besar dari yang lainnya, hal ini bisa disebabkan karena pada suhu tersebut terjadi reaksi yang sempurna karena jumlah oksigen 
mencukupi dan suhunya bisa menyebabkan kompresi paling besar. Setelah suhu udara dan bahan bakar $90 / 70^{\circ} \mathrm{C}$ terjadi daya mesin tidak naik bahkan turun drastis hal ini bisa disebabkan adanya pemuaian udara terlalu besar sesuai dengan persamaan (10) dan (13) dimana volume udara tetap tapi massanya berkurang sehingga kadar oksigen tidak mencukupi akibatnya pembakaran tidak sempurna, begitu juga volume bahan bakar tetap tapi massanya menurun.

Suhu bahan bakar bisa mempengaruhi daya mesin seperti yang terlihat pada gambar. Suhu semakin tinggi pada putaran mesin yang sama power mesin akan semakin tinggi. Terjadi seperti ini bisa disebabkan karena.

1. Dalam proses pembakaran di dalam silinder bahan bakar tidak terlalu banyak menyerap energi karena suhunya sudah lebih tinggi dari suhu bahan bakar pada keadaan standar.

2. Dalam proses pembakaran akan menyebabkan bahan bakar mudah terbakar karena suhu bahan bakar sudah tingggi.

3. Dengan suhu lebih tinggi volume membesar sehingga bahan bakar akan mudah mengkabut, akibatnya mudah terbakar.

Gambar 3 terlihat grafik peningkatan daya berdasarkan persamaan (9), pada suhu udara dan bahan bakar $80 / 50^{\circ} \mathrm{C}$ terjadi kenaikan daya sedikit sekali setelah suhunya dinaikkan, maka peningkatan daya terjadi bahkan pada suhu $90 / 70^{\circ} \mathrm{C}$ terjadi peningkatan daya maksimum bisa mencapai $2 \%$ lebih pada putaran mesin $2000 \mathrm{rpm}$. Setelah udara suhunya dinaikkan lagi dengan suhu bahan bakar tetap akibatnya terjadi penurunan daya sampai $12 \%$ di bawah daya standar.

Suhu bahan bakar dan suhu udara yang masuk ke silinder bisa mempengaruhi daya mesin seperti yang terlihat pada Gambar 3. Suhu semakin tinggi pada putaran mesin yang sama power mesin akan semakin tinggi. Terjadi seperti ini bisa disebabkan karena:

1. Suhu udara yang masuk ke dalam silinder akan menentukan hasil akhir dari kompresi di dalam silinder, semakin tinggi suhu yang dikompresi akan semakin tinggi suhu hasil kompresinya. Semakin tinggi suhu udara akan membuat pembakaran semakin sempurna.

2. Dalam proses pembakaran di dalam silinder, udara dan bahan bakar tidak terlalu banyak menyerap energi karena suhunya sudah lebih tinggi dari suhu udara dan bahan bakar pada keadaan standar.

3. Dalam proses pembakaran akan menyebabkan bahan bakar mudah terbakar karena suhu bahan bakar tingggi dan juga suhu udara di dalam silinder sudah tinggi.

4. Pada suhu tinggi ikatan antar molekul bahan bakar maupun udara akan lebih kecil sehingga mudah bereaksi karena jarak antar molekul lebih jauh dan permukaan yang kontak antara udara dengan bahan bakar lebih luas.

5. Dengan suhu bahan bakar dan udara tinggi maka volume membesar sehingga bahan bakar akan mudah mengkabut dan direaksikan dengan udara yang bersuhu tinggi maka akan mudah terbakar.

6. Gambar 1 sd 3 menjelaskan bahwa garis yang teratas pada semua putaran mesin adalah suhu gabungan antara bahan bakar dan udara yang bersuhu $70^{\circ} \mathrm{C}$ untuk bahan bakar dan $90^{\circ} \mathrm{C}$ untuk udara.

7. Suhu udara dinaikkan lagi massa jenis udara turun sehingga dengan volume yang sama massanya berkurang karena massa jenisnya turun, Suhu bahan bakar dan suhu udara berpengaruh terhadap SFC, Gambar 4 menunjukkan bahwa suhu udara $90^{\circ} \mathrm{C}$ dan suhu bahan bakar $70^{\circ} \mathrm{C}$ mempunyai SFC yang paling rendah untuk semua jenis putaran mesin, 


\section{KILAT}

suhu udara dinaikan dan suhu bahan bakar tetap $70^{\circ} \mathrm{C}$ akan membuat SFC naik. SFC paling tinggi pada suhu udara dan suhu bahan bakar standar dan suhu udara diatas $90^{\circ} \mathrm{C}$.

Suhu udara terlalu tinggi melebihi suhu $90^{\circ} \mathrm{C}$ bisa menyebabkan massa udara berkurang karena massa jenisnya turun sedangkan pada keadaan suhu udara dibawah $90^{0} \mathrm{C}$ massa jenisnya baik tapi suhu akhir kompresi kurang tinggi sehingga pembakaran tidak sempurna.

Pada putaran sekitar 2000 rpm semua SFC mengalami penurunan, dengan sepintas bisa kita simpulkan bahwa pada putaran tersebut pemakaian bahan bakar akan hemat. Penghematan bahan bakar paling irit adalah pada suhu udara $90^{\circ} \mathrm{C}$ dan suhu bahan bakar $70^{0} \mathrm{C}$, bisa terjadi demikian kemungkinan disebabkan kecepatan piston dan hasil kompresi optimum serta waktu pembakaran cukup. Putaran mesin diatas 2000 rpm pemakaian bahan bakar lebih boros karena kemungkinan bisa disebabkan waktu pembakaran terlalu singkat, jumlah udaranya kurang, reaksi bahan bakar dan udara kurang sempurna.

Pada putaran $2000 \mathrm{rpm}$ hamper sama dengan putaran $1000 \mathrm{rpm}$ sehingga kalau mengendarai kendaraan sebaiknya pada putaran antara putaran tersebut supaya hemat bahan bakar dengan daya yang sudah cukup terpenuhi. Disarankan jangan mengendarai kendaraan dengan putaran mesin diatas 3000 rpm karena memakai SFC terlalu tinggi sehingga boros.

Suhu bahan bakar dan suhu udara tidak begitu kelihatan berpengaruh berdasarkan dari gambar 5 karena terlihat semua jenis suhu berimpit pada putaran mesin yang sama, tapi sebenarnya tidak demikian karena selisihnya kecil sekitar $0.002 \mathrm{~kg} / \mathrm{jam}$ HP kalau 50 HP sudah selisih $0.1 \mathrm{~kg}$ bahan bakar. Dari grafik ini terlihat jelas perbedaan nilai SFC pada putaran mesin yang berbeda, putaran mesin 4000 rpm SFC nya bisa 3 kali SFC putaran 2000 rpm.

Penghematan pemakaian bahan bakar bisa dilihat pada grafik Gambar 6, semakin tinggi grafiknya semakin hemat pemakaian bahan bakarnya. Urutan yang hemat bahan bakar adalah pada putaran mesin $2000 \mathrm{rpm}, 1000 \mathrm{rpm}, 3000 \mathrm{rpm}$ dan $4600 \mathrm{rpm}$, begitu juga pengaruh suhu bisa dipilih pada SFC yang paling tinggi. SFC yang paling hemat rata-rata pada suhu udara dan suhu bahan bakar sekitar $90 / 70^{\circ} \mathrm{C}$. Bisa terjadi pada suhu $90 / 70^{\circ} \mathrm{C}$ kemungkinan karena jumlah oksigen terpenuhi, pembakaran bahan bakar bisa sempurna, dan suhu kompresi sudah cukup tinggi serta bidang kontak sudah cukup baik. Setelah suhu tersebut penghematan bahan bakar akan turun drastic karena kemungkinan suhu udara terlalu panas sehingga nassa jenisnya turun sehingga massa udara yang masuk jadi kurang.

\section{KESIMPULAN}

Beberapa kesimpulan penelitian ini adalah:

a) Daya maksimum terletak pada suhu bahan bakar $70^{\circ} \mathrm{C}$.

b) Daya maksimum dari gabungan suhu terletak pada suhu bahan bakar $70^{\circ} \mathrm{C}$ dan suhu udara $90^{\circ} \mathrm{C}$.

c) SFC yang optimum adalah yang minimum terjadi pada suhu bahan bakar $70^{\circ} \mathrm{C}$ dan suhu udara $90^{\circ} \mathrm{C}$ serta pada putaran mesin sekitar $2000 \mathrm{rpm}$.

d) Suhu bahan bakar $70^{0} \mathrm{C}$ dan suhu udara $90^{\circ} \mathrm{C}$ efisiensi maksimum dari SFC sekitar $2 \%$.

e) Suhu bahan bakar $70^{\circ} \mathrm{C}$ dan suhu udara $90^{\circ} \mathrm{C}$ dapat meningkatkan daya sekitar $2 \%$. 


\section{DAFTAR PUSTAKA}

[1] Birtok-Baneasa C., S Rațiu and T Hepuț, 2017, Influence of intake air temperature on internal combustion engine operation, International Conference on Applied Sciences (ICAS2016) IOP Publishing IOP Conf. Series: Materials Science and Engineering 163 (2017) 012039 doi:10.1088/1757-899X/163/1/012039.

[2] Can Cinar, Ahmet Uyumaz HamitSolmaz , Fatih Sahin, Seyfi Polat, Emre Yilmaz, 2015, Effects Of Intake Air Temperature On Combustion, Performance Andemission Characteristics Of A HCCI Engine Fueled With The Blends Of 20\% N-Heptane And 80\% Isooctane Fuels, Fuel Processing Technology 130 (2015) 275-281.

[3] Gowthaman S, A.P. Sathiyagnanam, 2016, Eff ects of charge temperature and fuel injection pressure on HCCI engine, Alexandria Engineering Journal,2016, 55, $119-125$. Available online 3 February 2016.

[4] Hindren A. Saber, Ramzi R. Ibraheem Al-Barwari, Ziyad J. Talabany, 2013, Effect Of Ambient Air Temperature On Specific Fuel Consumption Of Naturally Aspirated Diesel Engine, Journal of Science and Engineering Vol. 1 (1), 2013, 1-7

[5] Irawan Bambang, 2017, Perhitungan Energi Pembakaran Bahan Bakar di Dalam Silinder Mesin Bensin, Prosiding SNTT 2017 - Politeknik Negeri Malang Volume 3 - ISSN: 24769983.

[6] Kanna kumar J., P. Mallikarjuna Reddy, K. Hemachandra Reddy, 2014, Effect Of Fuel Temperature On Diesel Engine Performance and Emissions using Cotton Seed Based BioDiesel And Additive Ac2010a, International Journal of Green Chemistry and Bioprocess, 2014; 4(2): 9-13 